\title{
Investigation on the association between IL-10 C819T gene polymorphisms and susceptibility to gastric cancer
}

\author{
L. Li ${ }^{1}$, X.Y. Tang ${ }^{2}$, L.M. Ye ${ }^{1}$, Q. Yang ${ }^{1}$ and Y. Li ${ }^{1}$ \\ ${ }^{1}$ Gastrointestinal Department of Internal Medicine, \\ Guizhou Provincial People's Hospital, Guiyang, China \\ ${ }^{2}$ Gastrointestinal Department of Internal Medicine, \\ Zhongnan Hospital of Wuhan University, Wuhan, China \\ Corresponding author: L. Li \\ E-mail: lilange@163.com
}

Genet. Mol. Res. 15 (4): gmr15047915

Received October 27, 2015

Accepted June 13, 2016

Published December 19, 2016

DOI http://dx.doi.org/10.4238/gmr15047915

Copyright (C) 2016 The Authors. This is an open-access article distributed under the terms of the Creative Commons Attribution ShareAlike (CC BY-SA) 4.0 License.

\begin{abstract}
We conducted a case-control study to investigate the association between the interleukin-10 (IL-10) C819T polymorphism and susceptibility to gastric cancer in a Chinese population. A total of 157 patients with gastric cancer and 249 controls were consecutively enrolled from the Guizhou Provincial People's Hospital between October 2012 and February 2015. The polymerase chain reactionrestriction fragment length polymorphism technique was used to genotype for $I L-10$ C819T. As determined by $\chi^{2}$-test, there was a significant difference in genotype distributions of $I L-10 \mathrm{C} 819 \mathrm{~T}$ between gastric cancer patients and controls $\left(\chi^{2}=7.09 ; \mathrm{P}=0.03\right)$. Based on unconditional logistic regression analysis, the TT genotype of $I L-10$ C819T was significantly associated with increased risk of gastric cancer when compared with that of the $\mathrm{CC}$ genotype [odds ratio $(\mathrm{OR})=2.24$;
\end{abstract}


$95 \%$ confidence interval $(\mathrm{CI})=1.17-4.26 ; \mathrm{P}=0.008]$. In a dominant model, we found that the CT + TT genotype of IL-10 C819T was associated with susceptibility to gastric cancer compared to that of the $\mathrm{CC}$ genotype $(\mathrm{OR}=1.63 ; 95 \% \mathrm{CI}=1.02-2.64)$. In a recessive model, the TT genotype of $I L-10 \mathrm{C} 819 \mathrm{~T}$ was correlated with a higher risk of gastric cancer when compared with that of the $\mathrm{CC}+\mathrm{CT}$ genotype (OR $=1.75 ; 95 \% \mathrm{CI}=1.01-3.02)$. In conclusion, our study suggests that the IL-10 C819T polymorphism is associated with an increased risk of gastric cancer in co-dominant, dominant, and recessive models.

Key words: IL-10 C819T; Polymorphism; Gastric cancer

\section{INTRODUCTION}

Gastric cancer is the fifth most common malignancy and the third leading cause of cancer death worldwide (International Agency for Research on Cancer, 2012). It is indicated that Helicobacter pylori infections are associated with susceptibility to gastric cancer (Figueiredo et al., 2015; Venerito et al., 2015). However, the precise etiology of this cancer remains unclear. Many previous studies have reported that polymorphisms in inflammationrelated genes, such as tumor necrosis factor-alpha, toll-like receptors, and interleukins (IL), may be involved in the development of gastric cancer (Assis et al., 2014; Castaño-Rodríguez et al., 2014; Li et al., 2014; Qadri et al., 2014).

IL-10 is a pleiotropic cytokine, and a wealth of evidence supports its regulatory role in carcinogenesis and tumor growth (Tanikawa et al., 2012; Holan et al., 2014; Qi et al., 2014; Yu et al., 2014). There are several polymorphisms in the $I L-10$ gene, and IL-10 C819T (rs1800871) is a common single nucleotide polymorphism (SNP) in the promoter region. Many studies have reported the association between the $I L-10 \mathrm{C} 819 \mathrm{~T}$ gene polymorphism and development of gastric cancer, but the results are inconclusive (Kamangar et al., 2006; Sugimoto et al., 2007; Xiao et al., 2009; Sun et al., 2010; Liu et al., 2011; Xue et al., 2012; Zeng et al., 2012). Therefore, we carried out a hospital-based case-control study to evaluate the correlation between the $I L-10 \mathrm{C} 819 \mathrm{~T}$ polymorphism and susceptibility to gastric cancer in a Chinese population.

\section{MATERIAL AND METHODS}

\section{Patients}

Samples from a total of 157 patients with gastric cancer were consecutively collected from the Gastrointestinal Department of Internal Medicine, Guizhou Provincial People's Hospital between October 2012 and February 2015. These patients received gastrointestinal endoscopy and were diagnosed independently by two pathologists.

Control samples were consecutively were collected from individuals who obtained regular health examinations. All control subjects received the gastrointestinal endoscopy and were confirmed to be free of gastric cancer by pathologists. All control subjects were free of cancers, digestive diseases, and serious kidney and liver diseases. Finally, a total of 249 subjects were recruited as controls.

Genetics and Molecular Research 15 (4): gmr15047915 
The demographic, lifestyle, and clinical information were collected from medical records, including gender, age, family history of cancer, body mass index (BMI), tobacco smoking, alcohol consumption, tumor-node-metastasis (TNM) stage, Lauren classification, and presence of $H$. pylori infection. The $H$. pylori infection was determined by a rapid urea breath test.

Signed informed consent was obtained from each participant prior to joining this study, and the protocol was approved by the Ethics Committee of Guizhou Provincial People's Hospital.

\section{DNA extraction and genotyping}

Collected blood samples were stored in a tube with ethylene diamine tetraacetic acid and kept at $-20^{\circ} \mathrm{C}$ until use. TIANamp Blood DNA Kit (Tiangen, Beijing, China) was used to perform DNA extraction. The polymerase chain reaction-restriction fragment length polymorphism (PCR-RFLP) technique was used to genotype for the $I L$ $10 \mathrm{C} 819 \mathrm{~T}$ polymorphism. The forward and reverse primers of $I L-10 \mathrm{C} 819 \mathrm{~T}$ for PCR were 5'-TCATTCTATGTGCTGGAGATGG-3' and 5'-TGGGGGAAGTGGGTAAGAGT-3', respectively. The restriction enzyme for $I L-10 \mathrm{C} 819 \mathrm{~T}$ was $M s e$. The digested fragments for the $\mathrm{C}$ allele of $I L-10 \mathrm{C} 819 \mathrm{~T}$ were 93 and $116 \mathrm{bp}$, and the fragment for the T allele was $209 \mathrm{bp}$. The PCR consisted of: denaturation at $95^{\circ} \mathrm{C}$ for $5 \mathrm{~min} ; 30$ cycles of denaturation at $95^{\circ} \mathrm{C}$ for $30 \mathrm{~s}$, annealing at $59^{\circ} \mathrm{C}$ for $60 \mathrm{~s}$, and extension at $72^{\circ} \mathrm{C}$ for $60 \mathrm{~s}$; and a final extension step at $72^{\circ} \mathrm{C}$ for $10 \mathrm{~min}$.

\section{Statistical analysis}

The demographic, lifestyle, and clinical data as well as genotype distributions between gastric cancer patients and control subjects were analyzed by chi-square test. The goodness-of-fit $\chi^{2}$-test was used to analyze whether the genotype distribution of $I L-10$ C819T deviated from the Hardy-Weinberg equilibrium (HWE). The association between demographic, lifestyle, and clinical characteristics and the development of gastric cancer was estimated by univariate logistic regression analysis. Unconditional regression analysis was used to analyze the association between the $I L-10 \mathrm{C} 819 \mathrm{~T}$ polymorphism and risk of gastric cancer. Odds ratios (ORs) and 95\% confidence intervals (CIs) were calculated to describe the results. The statistical analysis was conducted by the SPSS 17.0 statistical software (SPSS, Chicago, IL, USA).

\section{RESULTS}

The demographic and clinical characteristics of gastric cancer patients and control subjects are described in Table 1. Compared with the controls, patients with gastric cancer were more likely to be male $(\mathrm{OR}=1.53 ; 95 \% \mathrm{CI}=1.00-2.36)$, be older $(\mathrm{OR}=1.57 ; 95 \% \mathrm{CI}$ $=1.03-2.40)$, have a higher $\mathrm{BMI}(\mathrm{OR}=1.96 ; 95 \% \mathrm{CI}=1.15-3.34)$, have a habit of alcohol consumption $(\mathrm{OR}=1.69 ; 95 \% \mathrm{CI}=1.11-2.58)$, and suffer from $H$. pylori infection $(\mathrm{OR}=1.97$; $95 \% \mathrm{CI}=1.29-3.01)$. However, no significant difference was identified between gastric cancer patients and control subjects in terms of tobacco smoking and family history of cancer. Of 157 patients with gastric cancer, $73(46.50 \%)$ of them were at TNM stage I-II, $84(53.50 \%)$ were at TNM stage III-IV, $82(52.23 \%)$ were intestinal type, and 75 (47.77\%) were diffuse type.

Genetics and Molecular Research 15 (4): gmr15047915 
Table 1. Characteristics of patients with gastric cancer and control subjects.

\begin{tabular}{|c|c|c|c|c|c|c|c|}
\hline Variables & Patients & $\%$ & Controls & $\%$ & $\chi^{2}$ test & OR $(95 \% \mathrm{CI})$ & P value \\
\hline \multicolumn{8}{|l|}{ Age, years } \\
\hline$<55$ & 65 & 41.40 & 131 & 52.61 & & 1.00 (Ref.) & - \\
\hline$\geq 55$ & 92 & 58.60 & 118 & 47.39 & 4.85 & $1.57(1.03-2.40)$ & 0.03 \\
\hline \multicolumn{8}{|l|}{ Gender } \\
\hline Female & 57 & 36.31 & 116 & 46.59 & & 1.00 (Ref.) & - \\
\hline Male & 100 & 63.69 & 133 & 53.41 & 4.16 & $1.53(1.00-2.36)$ & 0.04 \\
\hline \multicolumn{8}{|l|}{ BMI } \\
\hline$<55$ & 117 & 74.52 & 212 & 85.14 & & 1.00 (Ref.) & - \\
\hline$\geq 55$ & 40 & 25.48 & 37 & 14.86 & 7.06 & $1.96(1.15-3.34)$ & 0.008 \\
\hline \multicolumn{8}{|c|}{ Tobacco smokers } \\
\hline No & 88 & 56.05 & 159 & 63.86 & & 1.00 (Ref.) & - \\
\hline Yes & 69 & 43.95 & 90 & 36.14 & 2.46 & $1.39(0.90-2.12)$ & 0.12 \\
\hline \multicolumn{8}{|c|}{ Alcohol consumption } \\
\hline No & 71 & 45.22 & 145 & 58.23 & & 1.00 (Ref.) & - \\
\hline Yes & 86 & 54.78 & 104 & 41.77 & 6.55 & $1.69(1.11-2.58)$ & 0.01 \\
\hline \multicolumn{8}{|c|}{ Family history of cancer } \\
\hline No & 143 & 91.08 & 238 & 95.58 & & 1.00 (Ref.) & - \\
\hline Yes & 14 & 8.92 & 11 & 4.42 & 3.37 & $2.12(0.87-5.30)$ & 0.07 \\
\hline \multicolumn{8}{|c|}{ H. pylori infection } \\
\hline No & 67 & 42.68 & 148 & 59.44 & & 1.00 (Ref.) & - \\
\hline Yes & 90 & 57.32 & 101 & 40.56 & 10.86 & $1.97(1.29-3.01)$ & 0.001 \\
\hline \multicolumn{8}{|c|}{ TNM stage } \\
\hline I-II & 73 & 46.50 & & & & & \\
\hline III-IV & 84 & 53.50 & & & & & \\
\hline \multicolumn{8}{|c|}{ Lauren classification } \\
\hline Intestinal & 82 & 52.23 & & & & & \\
\hline Diffuse & 75 & 47.77 & & & & & \\
\hline
\end{tabular}

The number of CC, CT, and TT genotypes of $I L-10$ C819T were 38 (24.20\%), 83 (52.87\%), and $36(22.93 \%)$ in gastric cancer patients, respectively. The number of CC, CT, and TT genotypes of IL-10 C819T were 85 (34.14\%), 127 (51.00\%), and $36(14.46 \%)$ in control subjects, respectively (Table 2). By the $\chi^{2}$-test, there was a significant difference between genotype distributions of $I L-10 \mathrm{C} 819 \mathrm{~T}$ in gastric cancer patients and controls $\left(\chi^{2}=7.09\right.$; P $=0.03$ ). By chi-square test, the genotype distributions of $I L-10 \mathrm{C} 819 \mathrm{~T}$ did not deviate from the HWE in gastric cancer patients and control subjects, and the P values were 0.47 and 0.30 , respectively.

Table 2. Distribution of $I L-10$ C819T between gastric cancer patients and controls.

\begin{tabular}{l|c|c|c|c|c|c|c|c}
\hline IL-10 C819T & Patients & $\%$ & Controls & $\%$ & $\chi^{2}$ test & P value & \multicolumn{2}{|c}{ P for HWE } \\
\cline { 3 - 9 } & & & & & & & In cases & \\
\hline CC & 38 & 24.20 & 85 & 34.14 & & & & \\
\hline CT & 83 & 52.87 & 127 & 51.00 & & & 0.47 & 0.30 \\
\hline TT & 36 & 22.93 & 36 & 14.46 & 7.09 & 0.03 & 0.47 . \\
\hline
\end{tabular}

By unconditional logistic regression analysis, the TT genotype of $I L-10 \mathrm{C} 819 \mathrm{~T}$ was significantly associated with increased risk of gastric cancer when compared with the CC genotype $(\mathrm{OR}=2.24 ; 95 \% \mathrm{CI}=1.17-4.26 ; \mathrm{P}=0.008)$ (Table 3$)$. In a dominant model, we found that the $\mathrm{CT}+\mathrm{TT}$ genotype of $I L-10 \mathrm{C} 819 \mathrm{~T}$ was associated with susceptibility to gastric cancer compared to the $\mathrm{CC}$ genotype $(\mathrm{OR}=1.63 ; 95 \% \mathrm{CI}=1.02-2.64 ; \mathrm{P}=0.03)$. In a recessive model, the TT genotype of $I L-10 \mathrm{C} 819 \mathrm{~T}$ was correlated with a higher risk of gastric cancer when compared with the $\mathrm{CC}+\mathrm{CT}$ genotype $(\mathrm{OR}=1.75 ; 95 \% \mathrm{CI}=1.01-3.02 ; \mathrm{P}=0.03)$.

Genetics and Molecular Research 15 (4): gmr15047915 
Table 3. Association between $I L-10 \mathrm{C} 819 \mathrm{~T}$ gene polymorphisms and development of gastric cancer.

\begin{tabular}{|c|c|c|c|c|c|c|}
\hline$I L-10 \mathrm{C} 819 \mathrm{~T}$ & Patients & $\%$ & Controls & $\%$ & OR $(95 \% \mathrm{CI})^{1}$ & P value \\
\hline \multicolumn{7}{|l|}{ Co-dominant } \\
\hline $\mathrm{CC}$ & 38 & 24.20 & 85 & 34.14 & 1.0 (Ref.) & - \\
\hline CT & 83 & 52.87 & 127 & 51.00 & $1.46(0.89-2.42)$ & 0.11 \\
\hline TT & 36 & 22.93 & 36 & 14.46 & $2.24(1.17-4.26)$ & 0.008 \\
\hline \multicolumn{7}{|l|}{ Dominant } \\
\hline $\mathrm{CC}$ & 38 & 24.20 & 85 & 34.14 & 1.0 (Ref.) & - \\
\hline $\mathrm{CT}+\mathrm{TT}$ & 119 & 75.80 & 163 & 65.46 & $1.63(1.02-2.64)$ & 0.03 \\
\hline \multicolumn{7}{|l|}{ Recessive } \\
\hline $\mathrm{CC}+\mathrm{CT}$ & 121 & 77.07 & 212 & 85.14 & 1.0 (Ref.) & - \\
\hline TT & 36 & 22.93 & 36 & 14.46 & $1.75(1.01-3.02)$ & 0.03 \\
\hline
\end{tabular}

${ }^{1}$ Adjusted for age, gender, BMI, alcohol consumption, and Helicobacter pylori infection.

\section{DISCUSSION}

We conducted a case-control study to investigate the association between the IL-10 C819T polymorphism and development of gastric cancer, and we found that the TT genotype of $I L-10 \mathrm{C} 819 \mathrm{~T}$ was associated with susceptibility to gastric cancer.

The $I L-10$ gene has a key role in regulating the complex network of reactions in the process of carcinogenesis. The level of $I L-10$ gene production is associated with autoimmunity, transplantation tolerance, and carcinogenesis. Functional polymorphisms of $I L-10$ could alter the anti-inflammatory process. Previous studies have investigated the association between the IL-10 C819T polymorphism and development of several kinds of cancers, such as breast cancer, prostate cancer, acute myeloid leukemia, lung cancer, and esophageal cancer (Kong et al., 2010; Liu et al., 2010; Yao et al., 2013; Yang and Fa, 2015; Zhang et al., 2015). Kong et al. (2010) conducted a study in a Chinese population and suggested that there was no association between the $I L-10 \mathrm{C} 819 \mathrm{~T}$ polymorphism and risk of breast cancer. Liu et al. (2010) identified the role of three SNPs in the promoter of $I L-10$ in the risk of prostate cancer, and they reported that $I L-10 \mathrm{C} 819 \mathrm{~T}$ was not a risk factor for prostate cancer. Yao et al. (2013) reported that the $I L-10$ C819T site was associated with acute myeloid leukemia in a Chinese population. Zhang et al. (2015) performed a case-control study with 330 lung cancer patients and 336 cancer free controls and reported that the $I L-10 \mathrm{C} 819 \mathrm{~T}$ polymorphism is a molecular marker for lung cancer susceptibility. Yang and $\mathrm{Fa}$ (2015) did not suggest a significant association between the IL-10 C819T polymorphism and susceptibility to esophageal cancer.

Previous studies have reported the association between the $I L-10 \mathrm{C} 819 \mathrm{~T}$ polymorphism and development of gastric cancer, but the results are inconclusive (Kamangar et al., 2006; Sugimoto et al., 2007; Xiao et al., 2009; Sun et al., 2010; Liu et al., 2011; Xue et al., 2012; Zeng et al., 2012). Several studies suggested that the $I L-10$ C819T polymorphism was associated with an increased risk of gastric cancer in Japanese and Chinese populations (Sugimoto et al., 2007; Sun et al., 2010; Xue et al., 2012; Zeng et al., 2012). However, some studies did not find a significant role for the $I L-10 \mathrm{C} 819 \mathrm{~T}$ polymorphism in susceptibility to gastric cancer (Kamangar et al., 2006; Xiao et al., 2009; Liu et al., 2011). In our study, we found that $I L-10$ C819T was correlated with the development of gastric cancer, and the results of our study are in line with the results of previous studies.

In conclusion, our study suggests that the $I L-10 \mathrm{C} 819 \mathrm{~T}$ polymorphism is associated with an increased risk of gastric cancer in co-dominant, dominant, and recessive models. Further studies with larger sample sizes are greatly needed to confirm our findings.

Genetics and Molecular Research 15 (4): gmr15047915 


\section{Conflicts of interest}

The authors declare no conflict of interest.

\section{ACKNOWLEDGMENTS}

We thank for the great help from nurses and doctors in our hospital, and they help us to collect the blood sample into our study.

\section{REFERENCES}

Assis S, Marques CR, Silva TM, Costa RS, et al. (2014). IL10 single nucleotide polymorphisms are related to upregulation of constitutive IL-10 production and susceptibility to Helicobacter pylori infection. Helicobacter 19: 168-173. http:// dx.doi.org/10.1111/hel.12119

Castaño-Rodríguez N, Kaakoush NO, Pardo AL, Goh KL, et al. (2014). Genetic polymorphisms in the Toll-like receptor signalling pathway in Helicobacter pylori infection and related gastric cancer. Hum. Immunol. 75: 808-815. http:// dx.doi.org/10.1016/j.humimm.2014.06.001

Figueiredo C, Costa S, Karameris A and Machado JC (2015). Pathogenesis of gastric cancer. Helicobacter 20 (Suppl 1): 30-35.http://dx.doi.org/10.1111/hel.12254

Holan V, Zajicova A, Javorkova E, Trosan P, et al. (2014). Distinct cytokines balance the development of regulatory T cells and interleukin-10-producing regulatory B cells. Immunology 141: 577-586. http://dx.doi.org/10.1111/imm.12219

International Agency for Research on Cancer (2012). Stomach cancer. estimated incidence, mortality and prevalence worldwide in 2012. Available at [http://globocan.iarc.fr/Pages/fact_sheets_cancer.aspx]. Accessed August 10, 2015.

Kamangar F, Abnet CC, Hutchinson AA, Newschaffer CJ, et al. (2006). Polymorphisms in inflammation-related genes and risk of gastric cancer (Finland). Cancer Causes Control 17: 117-125. http://dx.doi.org/10.1007/s10552-005-0439-7

Kong F, Liu J, Liu Y, Song B, et al. (2010). Association of interleukin-10 gene polymorphisms with breast cancer in a Chinese population. J. Exp. Clin. Cancer Res. 29: 72. http://dx.doi.org/10.1186/1756-9966-29-72

Li M, Wang Y and Gu Y (2014). Quantitative assessment of the influence of tumor necrosis factor alpha polymorphism with gastritis and gastric cancer risk. Tumour Biol. 35: 1495-1502. http://dx.doi.org/10.1007/s13277-013-1206-0

Liu J, Song B, Bai X, Liu W, et al. (2010). Association of genetic polymorphisms in the interleukin-10 promoter with risk of prostate cancer in Chinese. BMC Cancer 10: 456. http://dx.doi.org/10.1186/1471-2407-10-456

Liu J, Song B, Wang JL, Li ZJ, et al. (2011). Polymorphisms of interleukin-10 promoter are not associated with prognosis of advanced gastric cancer. World J. Gastroenterol. 17: 1362-1367. http://dx.doi.org/10.3748/wjg.v17.i10.1362

Qadri Q, Rasool R, Afroze D, Naqash S, et al. (2014). Study of TLR4 and IL-8 gene polymorphisms in H. pylori-induced inflammation in gastric cancer in an ethnic Kashmiri population. Immunol. Invest. 43: 324-336. http://dx.doi.org/10 $.3109 / 08820139.2013 .854378$

Qi M, Liu DM, Pan LL and Lin YX (2014). Interleukin-10 gene -592C >A polymorphism and susceptibility to gastric cancer. Genet. Mol. Res. 13: 8954-8961. http://dx.doi.org/10.4238/2014.October.31.10

Sugimoto M, Furuta T, Shirai N, Nakamura A, et al. (2007). Effects of interleukin-10 gene polymorphism on the development of gastric cancer and peptic ulcer in Japanese subjects. J. Gastroenterol. Hepatol. 22: 1443-1449. http:// dx.doi.org/10.1111/j.1440-1746.2006.04613.x

Sun F, Sun Y, Zhang D, Zhang J, et al. (2010). Association of interleukin-10 gene polymorphism with cachexia in Chinese patients with gastric cancer. Ann. Clin. Lab. Sci. 40: 149-155.

Tanikawa T, Wilke CM, Kryczek I, Chen GY, et al. (2012). Interleukin-10 ablation promotes tumor development, growth, and metastasis. Cancer Res. 72: 420-429. http://dx.doi.org/10.1158/0008-5472.CAN-10-4627

Venerito M, Vasapolli R, Rokkas T and Malfertheiner P (2015). Helicobacter pylori and Gastrointestinal Malignancies. Helicobacter 20 (Suppl 1): 36-39. http://dx.doi.org/10.1111/hel.12255

Xiao H, Jiang Y, Li R and Xia B (2009). Association of IL-10 gene polymorphisms with gastroduodenal diseases in Hubei Han population. Zhonghua Yi Xue Yi Chuan Xue Za Zhi 26: 423-426.

Xue H, Lin B, An J, Zhu Y, et al. (2012). Interleukin-10-819 promoter polymorphism in association with gastric cancer risk. BMC Cancer 12: 102. http://dx.doi.org/10.1186/1471-2407-12-102

Yang Y and Fa X (2015). Role of IL-10 gene polymorphisms on the susceptibility for esophageal cancer and its association with environmental factors. Int. J. Clin. Exp. Pathol. 8: 9580-9585.

Genetics and Molecular Research 15 (4): gmr15047915 
Yao CJ, Du W, Chen HB, Xiao S, et al. (2013). Associations of IL-10 gene polymorphisms with acute myeloid leukemia in Hunan, China. Asian Pac. J. Cancer Prev. 14: 2439-2442. http://dx.doi.org/10.7314/APJCP.2013.14.4.2439

Yu T, Lu Q, Ou XL, Cao DZ, et al. (2014). Clinical study on gastric cancer susceptibility genes IL-10-1082 and TNF-a. Genet. Mol. Res. 13: 10909-10912.http://dx.doi.org/10.4238/2014.December.19.12

Zeng X, Li Y, Liu T and Zhang J (2012). Diverse H. pylori strains, IL-10 promoter polymorphisms with high morbidity of gastric cancer in Hexi area of Gansu Province, China. Mol. Cell. Biochem. 362: 241-248. http://dx.doi.org/10.1007/ s11010-011-1149-y

Zhang YM, Mao YM and Sun YX (2015). Genetic polymorphisms of IL-6 and IL-10 genes correlate with lung cancer in never-smoking Han population in China. Int. J. Clin. Exp. Med. 8: 1051-1058.

Genetics and Molecular Research 15 (4): gmr15047915 